\title{
ISCHAEMIC HEART DISEASE, AORTIC ANEURYSMS, AND ATHEROSCLEROSIS IN THE CITY OF LONDON, 1868-1982
}

\author{
by
}

\section{RODNEY FINLAYSON*}

The rarity of thrombotic complications and overt clinical disease are possibly the only features that distinguish atherosclerosis in animals from the same condition in man. Yet the reason (or reasons) why a comparatively bland vascular disorder now presents as a lethal myocardial disease of high prevalence in modern western man is still largely unknown. A historical approach to the problem has received little attention, and apart from the classic study by Morris, ${ }^{1}$ few historical surveys, based on post-mortem reports, of ischaemic heart disease and its relationship to atherosclerosis have been attempted. To redress the balance in part, a fresh survey, based on autopsy reports dating back to 1868 at St Bartholomew's Hospital in the City of London and supplemented by records on autopsies performed at the City mortuary on the direction of the Coroner, is presented.

In October 1867, two registers, one of medical and the other of surgical post-mortem reports, were initiated at St Bartholomew's Hospital. The medical register continued, apart from an unexplained hiatus in the handwritten reports from May 1869 to March 1870, until it was combined with the surgical register into a single post-mortem register with typed reports on 1 January 1937 . The surgical register started with a flourish in October 1867, but within six months the reporting had become desultory, and by December 1868 it expired. The register restarted on 1 January 1884 , and continued without interruption until being integrated with the medical register in 1937.

The post mortems, with few exceptions, were performed by aspiring consultant physicians or surgeons until the early 1930s. The introduction of a printed systemized anatomical pro forma on alternate pages of the medical register in the 1880 s and of the surgical register some thirty years later significantly improved the quality of the reports. The pro forma lapsed with the typing of the records in 1937. During the Second World War, the hospital remained open for acute cases, but no post mortems were carried out during September-December 1939, and autopsy reports for 1940-44 were succinct. The immediate post-war years showed a gradual reopening of wards and the construction of new wards. Although a few clinical units were not transferred back to St Bartholomew's from the "war-time" sector hospital at Hill End, St Albans, until 1961, the related autopsy reports, carrying the prefix

*Rodney Finlayson, MD, FRCPath., Little Meadow, Limers Lane, Northam, Bideford, Devon.

${ }^{1}$ J.N. Morris, 'Recent history of coronary disease', Lancet, 1951, i: 1-7 and 69-73. 


\section{R. Finlayson}

P.M. H.E.H. (Hill End Hospital), from 1950 to 1961, were incorporated into the Bart's post-mortem registers and are included in the current survey. Reports on autopsies or autopsy material from other sources, carrying the prefix P.M.O., are excluded.

The earliest reports were often surprisingly detailed, a clinical summary accompanying the morbid anatomical description, together with such data as the name and age of the patient, the name of the consultant clinician, the clinical and pathological diagnosis, and the signature or initials of the prosector. However, a clinical summary soon became exceptional, being replaced by a numbered reference to the ward notes and then by little except a one-line clinical diagnosis, though those brought in dead to the hospital (B.I.D.s) were usually noted as such. The regular incorporation of a clinical summary in the reports dates from 1937. In general, histopathological data relating to the autopsies developed more or less progressively during the century under review.

The nationality of patients was not stated on autopsy reports, but it would be reasonable to assume that almost all, until the most recent decade, were British and caucasoid, and that the great majority had resided in London or the Home Counties. There was a space for "occupation" on the forms but more often than not it remained vacant. However, a sample analysis of the hospital death register (Table 1$)^{2}$ confirms that throughout the period studied the majority of patients who died in the hospital came from the London area (i.e. modern postal districts) although there has been, from the 1930 s onwards, a considerable increase in non-Londoners roughly matched, until recently, by a corresponding decrease in patients from the immediate environs of the hospital. Social data such as the residential address and occupation of the patient are listed in this register of deaths at the hospital. Detailed use of this voluminous record has not been made in the present study.

TABLE 1. RESIDENTIAL DISTRIBUTION OF PATIENTS AT ST BARTHOLOMEW'S HOSPITAL FROM AN ANALYSIS OF THE DEATH REGISTERS, 1868-1978

\begin{tabular}{|c|c|c|c|c|}
\hline Year & Deaths & $\%$ Local & $\begin{array}{l}\% \text { Within London } \\
\text { excluding Local }\end{array}$ & $\%$ Outside London \\
\hline 1868 & 586 & 77 & 17 & 6 \\
\hline 1878 & 655 & 72 & 23 & 5 \\
\hline 1888 & 803 & 80 & 16 & 4 \\
\hline 1898 & 640 & 52 & 38 & 10 \\
\hline 1908 & 720 & 56 & 34 & 10 \\
\hline 1918 & 460 & 55 & 33 & 12 \\
\hline 1928 & 614 & 40 & 40 & 20 \\
\hline 1938 & 500 & 16 & 52 & 32 \\
\hline 1948 & 341 & 22 & 41 & 37 \\
\hline 1958 & 511 & 25 & 40 & 35 \\
\hline 1968 & 750 & 28 & 43 & 29 \\
\hline 1978 & 838 & 39 & 25 & 36 \\
\hline
\end{tabular}

Notes

Local $=$ present postal districts EC1, EC4, N1, E2.

Within London $=$ within present postal districts.

The reports on autopsies performed at the City mortuary on the direction of the Coroner were completed on separate single-page printed pro formas by a variety of medical men, including hospital staff, police surgeons, general practitioners, and

\footnotetext{
2 Janet Foster, unpublished data.
} 


\section{Ischaemic heart disease, aortic aneurysms, and atherosclerosis in London}

Home Office pathologists, notably Sir Bernard Spilsbury before 1938. Since 1941, they have generally been performed by forensic pathologists, notably Prof. Keith Simpson. Prior to 1901, the medical details were usually brief and confined to evidence presented in court and recorded in the Coroner's own transcript of the proceedings. The inquisition and deposition records for 1938-40 do not exist; they were presumably destroyed during the fire-bomb air attack on the City at the end of December 1940. Since 1950, virtually all cases of death reported to the City Coroner have been subjected to post-mortem examination, but this was not so previously. The more recent Coroner's Officer's reports provide valuable data on the circumstances surrounding the patient's death, including a meticulous timing of events.

Initially, this survey was intended to determine the prevalence of fatal ischaemic heart disease associated with coronary atherosclerosis as well as the prevalence of severe coronary atherosclerosis by studying the hospital's post-mortem reports at regular time intervals between 1868 and 1982 . However, a preliminary appraisal showed that lack of descriptive data made it impossible to determine the prevalence of severe coronary disease for much of the period under review. As an alternative, the prevalence of atheromatous aneurysms of the lower abdominal aorta and contiguous common iliac arteries was selected in the hope that it would provide a crude index of severe atherosclerosis in which aneurysms were not present. Hospital reports were also analysed to determine whether the presence of severe atherosclerosis of the abdominal aorta had been recorded. The frequency of dissecting aneurysms of the aorta and of saccular or fusiform aneurysms of the thoracic segment of the aorta was also determined.

The records from the City mortuary were also analysed because post mortems on B.I.D.s at the hospital virtually ceased in May 1952. As with the hospital reports, only fatal cases of ischaemic heart disease associated with coronary atherostenosis or atherothrombosis are included in the study. Cases of coronary insufficiency associated with coronary arteritis, coronary emboli, aortic valvular or root disease, anomalous coronary arteries, and what may be described as "surgical mishaps" are excluded. As distinct from the hospital material, the prevalence of aortic aneurysms in the City mortuary cases has been limited to deaths due to the aneurysms rather than to their presence or that of a replacement prosthesis at autopsy irrespective of the cause of death. The reports to the Coroner were inadequate for determining the prevalence of severe aortic atherosclerosis.

\section{ISCHAEMIC HEART DISEASE}

In this paper, ischaemic heart disease has been identified with several earlier morphological diagnoses. Terms used during the first half of the period surveyed included calcareous atheroma, myomalacia cordis, chronic myocarditis, fibroid disease of the heart, degeneration of the muscles of the heart, fatty heart, cardiac necrosis, cardiac abscess, rent or rupture of the heart, pouch at the apex of the left ventricle and, not uncommonly in B.I.D.s, interstitial nephritis. In the majority of these cases, I found it reasonably easy to decide from the descriptive details in the post-mortem report whether or not a fatal coronary heart disease was present, using simple current forensic criteria. For examples, see Appendix I. In other instances, 


\section{R. Finlayson}

however, the datum was inadequate to justify revising the original diagnosis to one of ischaemic heart disease, even though on the documentary evidence available this seemed the most likely cause of death (see Appendix II). Such cases, which comprised a very small proportion of the total number of autopsy reports, were classified as half-cases of ischaemic heart disease. Two halves were converted into one positive case, and residual halves were rounded-up over a two-, three-, or five-year period.

In the second half of the survey, the original pathological diagnoses were generally accepted. A few cases diagnosed as coronary disease were excluded because the autopsy details did not fully support the diagnosis. A small number of reports listing a battery of pathological lesions, including a multiplicity of lethal conditions, were also excluded unless a summary indicated that ischaemic heart disease had been regarded as the immediate cause of death. Revision was also made to the reports in the 1930s of one prosector who, one suspects, had little liking for a diagnosis of coronary disease even when confronted by a ruptured myocardial infarct.

TABLE 2. ISCHAEMIC HEART DISEASE AND AORTIC ANEURYSMS AT AUTOPSY, ST BARTHOLOMEW'S HOSPITAL 1868, 1870-71 TO 1981-82

\begin{tabular}{|c|c|c|c|c|c|c|c|c|c|c|c|}
\hline \multirow[b]{2}{*}{ Years } & \multicolumn{3}{|c|}{ Post mortems } & \multicolumn{5}{|c|}{ Deaths from ischaemic heart disease } & \multicolumn{3}{|c|}{ No. of aortic aneurysms } \\
\hline & Total & $\begin{array}{l}\text { \% over } \\
40 \text { yrs } \\
\text { old }\end{array}$ & $\begin{array}{l}\% \text { over } \\
60 \text { yrs } \\
\text { old }\end{array}$ & $\begin{array}{l}\text { Died in } \\
\text { hospital }\end{array}$ & B.I.D. & Total & $\begin{array}{l}\text { \% all } \\
\text { P.M.'s }\end{array}$ & $\begin{array}{l}\text { \% in } \\
\text { over } \\
40^{\prime} \text { 's }\end{array}$ & $\begin{array}{l}\text { Lower } \\
\text { abdominal }\end{array}$ & Dissecting & Thoracic \\
\hline $1868,1870-71$ & $559^{*}$ & * $41 \cdot 4$ & $6 \cdot 1$ & 1 & 1 & 2 & $0 \cdot 36$ & $0 \cdot 87$ & 0 & 1 & 15 \\
\hline $1874-76$ & $727^{*}$ & * $37 \cdot 7$ & $8 \cdot 3$ & 1 & 1 & 2 & $0 \cdot 28$ & 0.74 & 0 & 0 & 20 \\
\hline $1879-81$ & $815^{\circ}$ & $* 36 \cdot 4$ & $6 \cdot 9$ & 1 & 0 & 1 & $0 \cdot 12$ & 0.33 & 1 & 2 & 22 \\
\hline $1884-85$ & 903 & $41 \cdot 9$ & $12 \cdot 3$ & 2 & 1 & 3 & 0.33 & 0.79 & $2(1)$ & $\overline{1}$ & 19 \\
\hline $1889-90$ & 965 & $38 \cdot 5$ & $10 \cdot 4$ & 1 & 3 & 4 & $0 \cdot 41$ & $1 \cdot 07$ & 2(1) & 1. & 15 \\
\hline 189 & 1121 & $36 \cdot 0$ & $10 \cdot 5$ & 3 & 2 & 5 & 0.45 & $1 \cdot 25$ & 1 & 2 & 24 \\
\hline $1899-1900$ & 991 & $44 \cdot 3$ & $8 \cdot 0$ & 1 & 3 & 4 & 0.40 & 0.90 & $1(1)$ & 0 & 6 \\
\hline $1904-05$ & 1058 & $36 \cdot 0$ & $9 \cdot 0$ & 3 & 1 & 4 & 0.38 & $1 \cdot 06$ & $2(1)$ & 2 & 12 \\
\hline 1909-10 & 1105 & $42 \cdot 7$ & $11 \cdot 7$ & 4 & 0 & 4 & 0.36 & 0.84 & 1 & 0 & 4 \\
\hline 1914-15 & 987 & $36 \cdot 4$ & $12 \cdot 9$ & 1 & 3 & 4 & 0.41 & $1 \cdot 13$ & 1 & 3 & 5 \\
\hline 191 & 834 & $50 \cdot 7$ & $16 \cdot 3$ & 6 & 0 & 6 & 0.72 & $1 \cdot 42$ & $1(1)$ & 1 & 10 \\
\hline 192 & 800 & $58 \cdot 3$ & $21 \cdot 3$ & 6 & 3 & 9 & $1 \cdot 12$ & 1.92 & 2 & 0 & 3 \\
\hline 1929-30 & 678 & $62 \cdot 8$ & $25 \cdot 4$ & 6 & 4 & 10 & 1.47 & $2 \cdot 34$ & 0 & 0 & 4 \\
\hline 1934-35 & 616 & $61 \cdot 6$ & $26 \cdot 2$ & 7 & 5 & 12 & 1.95 & $3 \cdot 17$ & 0 & 1 & 1 \\
\hline 1938-39 & 597 & $69 \cdot 3$ & $28 \cdot 7$ & 7 & 17 & 24 & $4 \cdot 02$ & $5 \cdot 80$ & 0 & 2 & 5 \\
\hline 1941 & 171 & $67 \cdot 5$ & $34 \cdot 4$ & 3 & 14 & 17 & - & - & 0 & 2 & 0 \\
\hline 1945 & 139 & $71 \cdot 2$ & $43 \cdot 2$ & 4 & 19 & 23 & - & - & 2 & 1 & 1 \\
\hline-47 & 390 & $66 \cdot 5$ & $33 \cdot 0$ & 9 & 40 & 49 & $12 \cdot 56$ & $18 \cdot 88$ & 2 & 4 & 2 \\
\hline $49-50$ & 481 & $76 \cdot 2$ & $38 \cdot 3$ & 13 & 59 & 72 & 14.97 & $19 \cdot 64$ & 1 & 1 & 1 \\
\hline $954-55$ & 542 & $75 \cdot 8$ & $39 \cdot 7$ & 29 & 0 & 29 & $5 \cdot 35$ & $7 \cdot 06$ & $10[2]$ & 1 & 3 \\
\hline $959-60$ & 638 & $78 \cdot 0$ & $43 \cdot 8$ & 37 & 0 & 37 & 5.80 & $7 \cdot 44$ & $5[1]$ & 4 & 2 \\
\hline $64-65$ & 584 & $76 \cdot 3$ & $42 \cdot 0$ & 44 & 2 & 46 & $7 \cdot 53$ & $9 \cdot 87$ & $14[9]$ & 2 & $1(1)$ \\
\hline 70 & 592 & $84 \cdot 6$ & $48 \cdot 8$ & 44 & 8 & 52 & $7 \cdot 43$ & $8 \cdot 78$ & $13[8]$ & $7(3)$ & 0 \\
\hline & 578 & $80 \cdot 6$ & $51 \cdot 2$ & 43 & 0 & 43 & $7 \cdot 44$ & $9 \cdot 23$ & $16[7]$ & & $2(2)$ \\
\hline & & $83 \cdot 5$ & & 38 & 0 & 38 & 8.46 & $10 \cdot 13$ & $20[4]$ & $5(1)$ & $2(1)$ \\
\hline $01-02$ & 427 & $4^{\circ}$ & $56 \cdot 7$ & 33 & 0 & 33 & $7 \cdot 73$ & $9 \cdot 19$ & $6[3]$ & 1 & 1(1) \\
\hline
\end{tabular}

Notes

*Medical post-mortem register only.

Lower abdominal aortic aneurysms: ()not primary atheromatous: [] post-prosthesis.

Dissecting aortic aneurysms: previous aortic abdominal prosthesis cases in parentheses.

Thoracic aortic aneurysms: non-syphilitic cases in parentheses. 


\section{Ischaemic heart disease, aortic aneurysms, and atherosclerosis in London}

Accepting these adjustments to the hospital reports it would seem from the figures presented in Table 2 that the prevalence of ischaemic heart disease was both low and altered little between $1868,1870-71$ and 1914-15, with the possible exception of a slight increase in the 1890 s that was not sustained into the first decade of the twentieth century. However, by 1919-20, the number of deaths from coronary heart disease averaged three per year and comprised 0.7 per cent of all post mortems and 1.4 per cent in those over the age of forty years. Thereafter, these figures had roughly doubled by $1929-30$, redoubled by $1938-39$, and increased tenfold by $1949-50$. The subsequent absence of B.I.D.s from the series makes comparison with the earlier results impossible, but the number of deaths in hospital from ischaemic heart disease since 1954-55 indicate a prevalence increasing less rapidly. The figures for 1981-82 hint at a small decline.

TABLE 3. ISCHAEMIC HEART DISEASE AND AORTIC ANEURYSMS AT AUTOPSY, ST BARTHOLOMEW'S HOSPITAL 1893-97 TO 1978-82

\begin{tabular}{|c|c|c|c|c|c|c|c|}
\hline \multirow{2}{*}{ Years } & \multirow{2}{*}{$\begin{array}{l}\text { PMs } \\
\text { Total }\end{array}$} & \multirow[b]{2}{*}{ D.I.H. } & \multicolumn{3}{|c|}{ Ischaemic heart disease } & \multicolumn{2}{|c|}{ Aneurysms } \\
\hline & & & B.I.D. & Total & $\%$ & $A b d$ & Diss. \\
\hline $1893-97$ & 2750 & 4 & 8 & 12 & 0.44 & $2(1)$ & 2 \\
\hline $1903-07$ & 2704 & 6 & 1 & 7 & $0 \cdot 26$ & $4(3)$ & 4 \\
\hline 1913-17 & 2253 & 7 & 3 & 10 & 0.44 & $2(1)$ & 4 \\
\hline $1918-22$ & 1911 & 13 & 0 & 13 & $0 \cdot 68$ & $2(1)$ & 5 \\
\hline 1923-27 & 1870 & 14 & 6 & 20 & $1 \cdot 07$ & & 2 \\
\hline $1933-37$ & 1557 & 19 & 20 & 39 & $2 \cdot 50$ & $2(1)$ & 8 \\
\hline $1940-44$ & 843 & 21 & 92 & 113 & $13 \cdot 40$ & 0 & 12 \\
\hline $1945-49$ & 99 & 32 & 124 & 156 & $\begin{array}{l}\text { 15.69 } \\
\text { B.I.D.s not }\end{array}$ & 5 & 6 \\
\hline 1953-57 & 1431 & 68 & 0 & 68 & $4 \cdot 75$ & $19[2]$ & 4 \\
\hline $1963-67$ & 1624 & 118 & 6 & 124 & $7 \cdot 27$ & $33[19]$ & $12(2)$ \\
\hline 1973-77 & 1330 & 107 & 2 & 109 & 8.05 & $36[15]$ & 8 \\
\hline $1978-82$ & 1122 & 95 & 0 & 95 & $8 \cdot 47$ & $30[9]$ & $8(1)$ \\
\hline
\end{tabular}

Notes

D.I.H.: died in hospital.

B.I.D.: brought in dead.

Abd.: Abdominal.

Diss.: Dissecting.

Figures in parentheses and brackets as in Table 2.

Table 3 presents the hospital figures for five-year periods from 1893-97 to 1978-82 and largely complements those given in Table 2 . The atypical post-mortem population during and immediately after the Second World War has almost certainly exaggerated the frequency of ischaemic heart disease for that period.

The two-year and five-year figures obtained from the records of post mortems conducted at the City of London mortuary or its pre-1877 equivalent are shown in Tables 4 and 5 . The ninefold increase in the number of deaths from ischaemic heart disease with only a threefold increase in the total number of autopsies performed between 1945-49 and 1953-57 (Table 5) and a roughly similar disparity in the figures for 1949-50 and 1954-55 (Table 4), probably signify in part an increased incidence of the disease and in greater part the loss of B.I.D.s from the hospital series. Since 1954-55, the number of autopsies carried out at the City mortuary has roughly doubled and the very high prevalence of sudden death from coronary disease has 


\section{R. Finlayson}

TABLE 4. DEATHS FROM ISCHAEMIC HEART DISEASE AND AORTIC ANEURYSMS, CITY OF LONDON MORTUARY 1869-70 TO 1981-82

\begin{tabular}{|c|c|c|c|c|c|c|c|c|}
\hline \multirow[b]{2}{*}{ Years } & \multirow[b]{2}{*}{ Total } & \multicolumn{2}{|c|}{ Post mortems } & \multicolumn{3}{|c|}{$\begin{array}{c}\text { Deaths from ischaemic } \\
\text { heart disease }\end{array}$} & \multicolumn{2}{|c|}{$\begin{array}{l}\text { No. of aortic } \\
\text { aneurysm deaths }\end{array}$} \\
\hline & & $\begin{array}{l}\text { \% over } \\
40 \text { yrs } \\
\text { old }\end{array}$ & $\begin{array}{l}\text { \% over } \\
60 \text { yrs } \\
\text { old }\end{array}$ & Total & $\begin{array}{l}\text { \% all } \\
P . M . ' s\end{array}$ & $\begin{array}{l}\text { Lower } \\
\text { abdominal }\end{array}$ & Dissecting & Thoracic \\
\hline $1869-70$ & 76 & $46 \cdot 0$ & $22 \cdot 3$ & 2 & 2.6 & 0 & 0 & 2 \\
\hline $1874-75$ & 88 & $57 \cdot 9$ & $19 \cdot 3$ & 4 & $4 \cdot 5$ & $1(1)$ & 0 & 3 \\
\hline $1879-80$ & 44 & $54 \cdot 5$ & $25 \cdot 0$ & 1 & $2 \cdot 3$ & 0 & 0 & 2 \\
\hline $1884-85$ & 63 & $60 \cdot 3$ & $27 \cdot 0$ & 2 & $3 \cdot 2$ & 0 & 2 & 4 \\
\hline $1889-90$ & 91 & $58 \cdot 2$ & $24 \cdot 2$ & 4 & $4 \cdot 4$ & 0 & 1 & 4 \\
\hline $1895-96$ & 95 & $51 \cdot 6$ & $20 \cdot 0$ & 4 & $4 \cdot 2$ & 0 & 0 & 2 \\
\hline 1899-1900 & 89 & $66 \cdot 3$ & $26 \cdot 3$ & 6 & $6 \cdot 7$ & 0 & 0 & 2 \\
\hline 1904-05 . & 132 & $58 \cdot 3$ & $27 \cdot 3$ & 8 & $6 \cdot 1$ & 0 & 0 & 6 \\
\hline 1909-10 & 170 & $57 \cdot 1$ & $23 \cdot 6$ & 14 & $8 \cdot 2$ & 0 & 0 & 11 \\
\hline 1914-15 & 170 & $66 \cdot 5$ & $31 \cdot 5$ & 15 & $8 \cdot 8$ & 0 & 0 & 3 \\
\hline 1919-20 & 187 & $61 \cdot 0$ & $26 \cdot 2$ & 19 & $10 \cdot 2$ & 0 & 3 & 0 \\
\hline $1924-25$ & 141 & $68 \cdot 8$ & $31 \cdot 2$ & 26 & $18 \cdot 4$ & 0 & 1 & 1 \\
\hline $1929-30$ & 185 & $66 \cdot 5$ & $29 \cdot 2$ & 35 & $18 \cdot 9$ & 1 & 3 & 3 \\
\hline $1934-35$ & 160 & $72 \cdot 5$ & $37 \cdot 7$ & 38 & $23 \cdot 8$ & 0 & 4 & 3 \\
\hline 1945 & 36 & $80 \cdot 6$ & $41 \cdot 7$ & 4 & - & 0 & 0 & 0 \\
\hline $1946-47$ & 93 & $79 \cdot 6$ & $44 \cdot 1$ & 20 & $21 \cdot 5$ & 0 & 0 & 0 \\
\hline 1949-50 & 119 & $75 \cdot 6$ & $38 \cdot 7$ & 18 & $15 \cdot 1$ & 1 & 2 & 0 \\
\hline $1954-55$ & 297 & $86 \cdot 2$ & $42 \cdot 8$ & 129 & $43 \cdot 4$ & 1 & 5 & 3 \\
\hline 1959-60 & 359 & $90 \cdot 5$ & $54 \cdot 3$ & 173 & $48 \cdot 2$ & $3(1)$ & 3 & 0 \\
\hline $1964-65$ & 403 & $88 \cdot 1$ & $47 \cdot 4$ & 190 & $47 \cdot 1$ & $5[2]$ & 2 & 1 \\
\hline $1969-70$ & 380 & $88 \cdot 4$ & $52 \cdot 6$ & 198 & $52 \cdot 1$ & $5[2]$ & 3 & 3 \\
\hline $1974-75$ & 546 & $82 \cdot 2$ & $46 \cdot 5$ & 219 & $40 \cdot 1$ & $10[5]$ & 8 & $2(2)$ \\
\hline 1979-80 & 608 & $88 \cdot 7$ & $52 \cdot 8$ & 274 & $45 \cdot 1$ & $11[6]$ & 6 & $2(1)$ \\
\hline $1981-82$ & 622 & $85 \cdot 2$ & $55 \cdot 7$ & 241 & $38 \cdot 7$ & $19[9]$ & 4 & 1(1) \\
\hline
\end{tabular}

Note: figures in parentheses and brackets as in Table 2.

TABLE 5. DEATHS FROM ISCHAEMIC HEART DISEASE AND AORTIC ANEURYSMS, CITY OF LONDON MORTUARY 1933-37 to 1978-82

\begin{tabular}{lccccc} 
Years & PMs & \multicolumn{2}{c}{ Ischaemic heart disease } & \multicolumn{2}{c}{ Aneurysms } \\
& Total & Total & \% all PMs & Abd. & Diss. \\
$1933-37$ & 317 & 72 & $22 \cdot 7$ & 0 & 6 \\
$1941-44$ & 94 & 23 & $24 \cdot 5$ & 0 & 0 \\
$1945-49$ & 234 & 36 & $15 \cdot 4$ & 0 & 1 \\
$1953-57$ & 764 & 338 & $44 \cdot 2$ & 3 & 8 \\
$1963-67$ & 996 & 480 & $48 \cdot 2$ & $9[5]$ & 10 \\
$1973-77$ & 1336 & 556 & $41 \cdot 6$ & $23[13]$ & $20(1)$ \\
$1978-82$ & 1534 & 633 & $41 \cdot 3$ & $35[16]$ & $14(1)$
\end{tabular}

'Note: figures in parentheses and brackets as in Table 2.

been sustained until very recently, when the figures suggest that a small reduction may have occurred. The data prior to 1945 are difficult to interpret because of the variability in the proportion of autopsies performed at the mortuary to the total number of cases referred to the Coroner. In many instances, the post mortem was done in the hospital and the report has been included in the hospital series. In some cases, particularly in the last century, no autopsy was performed, although this was less likely in a death from disease than from accident or suicide. Moreover, the retrospective diagnosis of ischaemic heart disease from the limited information in the early transcripts was, at best, tenuous. Nevertheless, the figures in Table 4 suggest 
Ischaemic heart disease, aortic aneurysms, and atherosclerosis in London

that the increased death rate from the coronary heart disease had started by 1909-10 and was fully established by 1919-20, but the subsequent great increase in prevalence indicated in the hospital series until 1949-50 is not wholly reflected in the City mortuary statistics.

The well-recognized sex difference in the incidence of ischaemic heart disease, particularly in those under the age of sixty, was apparent in both the hospital and City mortuary material. The disparity was accentuated by the predominance of males in both post-mortem series. Overall, the ratio of autopsies on males to females over the age of forty years was $2.3: 1$. Analysis of the results also confirmed that cardiac rupture secondary to myocardial infarction due to coronary disease is proportionally much commoner in females than in males (Table 6).

TABLE 6. AGE AND SEX DISTRIBUTION OF ISCHAEMIC HEART DISEASE AND AORTIC ANEURYSMS

\begin{tabular}{llllllll}
\multicolumn{1}{c}{ Condition } & Sex & \multicolumn{7}{c}{ Age (yrs.) } \\
& & $<40$ & $40-49$ & $50-59$ & $60-69$ & $>70$ & Total \\
Ischaemic heart disease & M & 67 & $327[1]$ & $976[14]$ & $1101[38]$ & $552[27]$ & $3023[80]$ \\
& F & 1 & 15 & $76[6]$ & $156[15]$ & $195[17]$ & $443[38]$ \\
Atheromatous abdominal & M & 0 & 0 & 30 & 80 & 92 & 202 \\
aneurysms & F & 0 & 0 & 2 & 13 & 22 & 37 \\
Dissecting aneurysms & M & 10 & 18 & 32 & 43 & 25 & 128 \\
& F & 1 & 6 & 12 & 8 & 7 & 34 \\
Thoracic aneurysms & M & 51 & 70 & 51 & 37 & 15 & 224 \\
& F & 4 & 12 & 5 & 7 & 8 & 36
\end{tabular}

Note: number of cases of cardiac rupture in brackets.

The City mortuary reports for $1978-80$ included 315 cases of ischaemic heart disease who were known to have died within one hour of collapsing from a heart attack. The great majority of the patients had held a sedentary job, and the high daytime as distinct from the relatively low nocturnal population in the City and its immediate neighbourhood probably explains why 26 per cent of the 315 cases had collapsed at work and a further 18 per cent in the street, as compared with 25 per cent at home. The current daytime population in the City itself is about 300,$000 ;^{3}$ it was 364,061 in $1911,301,384$ in $1891,261,061$ in 1881 , and 170,113 in 1866.4 The resident population has fallen from 50,652 in 1881 and 19,657 in $1911^{4}$ to about 5,300 in $1982 .^{5}$

\section{AORTIC ANEURYSMS}

The figures for atheromatous aneurysms of the lower abdominal aorta, including a few cases of atheromatous aneurysm of a common iliac artery, dissecting aneurysms

\footnotetext{
${ }^{3}$ Report-Policy and Resources Committee-the City's franchise, London, 9 February 1984.

4 Henry Percival Monckton, City of London day census, 1911, London, Simpkins, Marshall, Hamilton, Kent, 1911, pp. 73-81.

'Annual Report of the Corporation of London, 1982, p. 6.
} 


\section{R. Finlayson}

of the aorta, and saccular or fusiform aneurysms of the thoracic portion of the aorta in the hospital series are shown in Tables 2 and 3, and in the City mortuary series in Tables 4 and 5. The small numbers of traumatic aneurysms, aneurysms of the sinuses of Valsalva, and aneurysms of the upper abdominal aorta encountered in the survey are omitted.

Saccular aneurysms of the thoracic aorta, presumably entirely or almost entirely of syphilitic origin, dominated aortic pathology in the nineteenth century, and their decline has followed the introduction of increasingly effective therapeutic agents. Syphilitic aneurysms are currently almost curiosities, and aneurysms of the thoracic aorta are now much more likely to be associated with some condition other than syphilis. The long-recognized, though unexplained, predominance of syphilitic aneurysms in males is confirmed, and the age and sex distribution of all thoracic aneurysms included in the survey is shown in Table 6.

In contrast to the decline in syphilitic aneurysms, atheromatous aortic aneurysms have become more common: the increase first appearing in 1954-55 in the hospital material and a few years later in the City mortuary series. This increase may, in part, be related to the gradual increase in the mean age at death of the population. A more important factor has been the introduction of teflon and dacron prostheses in the treatment of these aneurysms. This attracted patients to the specialized surgical unit at the hospital from outside the City area, and inevitably some of these patients could be regarded as near-hopeless emergencies who, prior to replacement surgery, would have died elsewhere and thus not have been included in the present survey. However, an analysis of the non-surgically treated cases, aged 60-69 years, in the hospital series (Table 7) would suggest that there has been a real increase in atheromatous aortic aneurysms independent of age and therapy. The age and sex distribution of the aneurysms enumerated in the review is presented in Table 6.

The prevalence of dissecting aneurysms of the aorta has shown no dramatic changes. A possible slight increase in recent years may be largely a reflection of an ageing population. In a few cases, dissection of the thoracic aorta occurred in patients

TABLE 7. PREVALENCE OF ATHEROMATOUS ABDOMINAL AORTIC ANEURYSMS NOT SUBJECTED TO SURGERY IN PATIENTS AGED 60-69 YEARS AT AUTOPSY, ST BARTHOLOMEW'S HOSPITAL, 1893-97 TO 1978-82

$\begin{array}{lccc}\text { Years } & \begin{array}{c}\text { Total } \\ \text { PMs on patients } \\ \text { aged 60-69 }\end{array} & \text { Total } & \begin{array}{c}\text { Abdominal aneurysms } \\ \text { Prevalence of } \\ \text { untreated cases }\end{array} \\ 1893-97 & 189 & 1 & 0.5 \\ 1903-07 & 172 & 1 & 0.6 \\ 1913-17 & 201 & 0 & <0.5 \\ 1918-22 & 243 & 1 & 0.4 \\ 1923-27 & 253 & 3 & 1.2 \\ 1933-37 & 299 & 0 & <0.4 \\ 1940-44 & 150 & 0 & <0.7 \\ 1945-49 & 198 & 2 & 1.0 \\ 1953-57 & 349 & 6[1] & 1.4 \\ 1963-67 & 442 & 13[6] & 1.9 \\ 1973-77 & 370 & 12[5] & 3.3 \\ 1978-82 & 300 & 13[3] & \end{array}$

Note: number of surgically-treated patients in brackets. 


\section{Ischaemic heart disease, aortic aneurysms, and atherosclerosis in London}

who had survived replacement surgery of an atheromatous aneurysm of the abdominal aorta. The series included at least five cases of Marfan's syndrome. The age and sex distribution of the dissecting aneurysms reviewed is shown in Table 6.

\section{ATHEROSCLEROSIS}

The results of an attempt to determine the prevalence of severe atherosclerosis of the abdominal aorta by age and sex in the hospital cases from 1893-97 to 1978-82 are presented in Tables 8 and 9 and Figure 1. The inadequacy or absence of comment on the condition of the aorta in many reports in the surgical post-mortem register prior to 1913 means that the prevalence rates for 1893-97 and 1903-07 have been underestimated, albeit probably only slightly. The brevity of the reports during the Second World War makes the figures for 1940-44 highly suspect, and comment should be made that the results from 1953 to 1957 are based on post mortems that included very few B.I.D.s. The analysis also presupposes that in the absence of descriptive detail in the report the term "severe or very severe atheroma" meant much the same to a prosector of the 1890 s as it does to his modern counterpart. Accepting these several provisos, it would seem that the prevalence of severe atherosclerosis of the abdominal aorta has shown little change over the last ninety years, apart from a possible modest fall in older males in the period 1913-22, and that there is an age lag of about ten years between females and males in the intensity of the vascular lesion.

\section{DISCUSSION}

The present study exemplifies the shortcomings of a historical survey based on post-mortem reports, which are inevitably selective and, in the case of those submitted to the Coroner, especially so. Moreover, a geographically-limited survey may be subjected to local distortions that would be ironed out in a regional or national survey. On the other hand, a study of the original descriptive reports permits diagnostic revision and an assessment of the frequency of lesions that may be uncategorized in statistical tables based on death certificates.

On the assumption that the data presented are reasonably accurate, it would seem that the explosive increase in deaths from ischaemic heart disease started in the second decade of this century, that atheromatous aneurysms of the abdominal aorta have become more frequent over the past thirty years, and that there has been comparatively little alteration in the prevalence of severe aortic atherosclerosis over the last ninety years. In a survey based on the exceptionally detailed and accurate post-mortem reports at the London Hospital, Morris ${ }^{1}$ showed that there had been a six- to seven-fold increase in the number of deaths from recent coronary thrombosis and/or acute myocardial infarction between 1907-14 and 1944-49, with the steepest increase occurring in 1917-23, but the prevalence of severe coronary atheroma had not increased, indeed it had slightly diminished, over the same period. Subsequently, Morris $^{6}$ has re-emphasized that whilst occlusion and massive coronary thrombosis have become commoner during the present century, there is no evidence of any corresponding increase in the underlying coronary atheroma.

\footnotetext{
${ }^{6}$ J.N. Morris, Uses of epidemiology, 3rd ed., Edinburgh, Churchill Livingstone, 1975, pp. 14-15.
} 


\section{R. Finlayson}

TABLE 8. PREVALENCE OF SEVERE ATHEROSCLEROSIS OF ABDOMINAL AORTA IN MALES AT AUTOPSY, ST BARTHOLOMEW'S HOSPITAL, 1893-97 TO 1978-82

\begin{tabular}{|c|c|c|c|c|c|}
\hline $\begin{array}{l}\text { Years and } \\
\text { Age-group (Yrs.) }\end{array}$ & $\begin{array}{l}\text { Slight/ } \\
\text { Moderate }\end{array}$ & Severe & $\begin{array}{l}\text { Not } \\
\text { recorded }\end{array}$ & Total & $\begin{array}{l}\text { \% Severe } \\
\text { of Total }\end{array}$ \\
\hline $\begin{array}{r}1893-97 \\
40-49 \\
50-59 \\
60-69\end{array}$ & $\begin{array}{r}190 \\
120 \\
53\end{array}$ & $\begin{array}{l}16 \\
36 \\
37(1)\end{array}$ & $\begin{array}{l}54 \\
66 \\
44\end{array}$ & $\begin{array}{l}260 \\
222 \\
134\end{array}$ & $\begin{array}{r}6 \\
16 \\
28\end{array}$ \\
\hline $\begin{array}{r}1903-07 \\
40-49 \\
50-59 \\
60-69\end{array}$ & $\begin{array}{r}160 \\
110 \\
48\end{array}$ & $\begin{array}{l}11 \\
36 \\
44(1)\end{array}$ & $\begin{array}{l}59 \\
74 \\
35\end{array}$ & $\begin{array}{l}230 \\
220 \\
127\end{array}$ & $\begin{array}{r}5 \\
16 \\
35\end{array}$ \\
\hline $\begin{array}{r}1913-17 \\
40-49 \\
50-59 \\
60-69\end{array}$ & $\begin{array}{l}177 \\
162 \\
106\end{array}$ & $\begin{array}{r}7 \\
33 \\
38\end{array}$ & $\begin{array}{l}4 \\
8 \\
4\end{array}$ & $\begin{array}{l}188 \\
203 \\
148\end{array}$ & $\begin{array}{r}4 \\
16 \\
26\end{array}$ \\
\hline $\begin{array}{r}1918-22 \\
40-49 \\
50-59 \\
60-69\end{array}$ & $\begin{array}{l}213 \\
181 \\
129\end{array}$ & $\begin{array}{r}6 \\
32 \\
43\end{array}$ & $\begin{array}{r}5 \\
9 \\
11\end{array}$ & $\begin{array}{l}224 \\
222 \\
183\end{array}$ & $\begin{array}{r}3 \\
14 \\
23\end{array}$ \\
\hline $\begin{array}{r}1923-27 \\
40-49 \\
50-59 \\
60-69\end{array}$ & $\begin{array}{l}165 \\
152 \\
102\end{array}$ & $\begin{array}{l}9 \\
37 \\
63(2)\end{array}$ & $\begin{array}{l}35 \\
37 \\
24\end{array}$ & $\begin{array}{l}209 \\
226 \\
189\end{array}$ & $\begin{array}{r}4 \\
16 \\
33\end{array}$ \\
\hline $\begin{array}{r}1933-37 \\
40-49 \\
50-59 \\
60-69\end{array}$ & $\begin{array}{l}125 \\
181 \\
109\end{array}$ & $\begin{array}{l}11 \\
43 \\
80\end{array}$ & $\begin{array}{r}13 \\
7 \\
14\end{array}$ & $\begin{array}{l}149 \\
231 \\
203\end{array}$ & $\begin{array}{r}7 \\
19 \\
39\end{array}$ \\
\hline $\begin{array}{r}1940-44 \\
40-49 \\
50-59 \\
60-69\end{array}$ & $\begin{array}{l}35 \\
48 \\
36\end{array}$ & $\begin{array}{r}6 \\
29 \\
48\end{array}$ & $\begin{array}{l}31 \\
50 \\
44\end{array}$ & $\begin{array}{r}72 \\
127 \\
128\end{array}$ & $\begin{array}{r}8 \\
23 \\
37\end{array}$ \\
\hline $\begin{array}{r}1945-49 \\
40-49 \\
50-59 \\
60-69\end{array}$ & $\begin{array}{l}60 \\
78 \\
78\end{array}$ & $\begin{array}{c}7 \\
26(1) \\
63(2)\end{array}$ & $\begin{array}{l}13 \\
17 \\
14\end{array}$ & $\begin{array}{r}80 \\
121 \\
155\end{array}$ & $\begin{array}{r}9 \\
21 \\
41\end{array}$ \\
\hline $\begin{array}{r}1953-57 \\
40-49 \\
50-59 \\
60-69\end{array}$ & $\begin{array}{r}77 \\
155 \\
132\end{array}$ & $\begin{array}{c}7 \\
43(6) \\
80(5)\end{array}$ & $\begin{array}{l}10 \\
21 \\
21\end{array}$ & $\begin{array}{r}94 \\
219 \\
233\end{array}$ & $\begin{array}{r}7 \\
20 \\
34\end{array}$ \\
\hline $\begin{array}{r}1963-67 \\
40-49 \\
50-59 \\
60-69\end{array}$ & $\begin{array}{r}77 \\
163 \\
172\end{array}$ & $\begin{array}{c}4 \\
47(5) \\
102(11)\end{array}$ & $\begin{array}{r}6 \\
12 \\
15\end{array}$ & $\begin{array}{r}87 \\
222 \\
289\end{array}$ & $\begin{array}{r}5 \\
21 \\
35\end{array}$ \\
\hline $\begin{array}{r}1973-77 \\
40-49 \\
50-59 \\
60-69\end{array}$ & $\begin{array}{r}61 \\
128 \\
131\end{array}$ & $\begin{array}{l}6 \\
38(4) \\
87(12)\end{array}$ & $\begin{array}{l}1 \\
4 \\
6\end{array}$ & $\begin{array}{r}68 \\
170 \\
224\end{array}$ & $\begin{array}{r}9 \\
22 \\
39\end{array}$ \\
\hline $\begin{array}{r}1978-82 \\
40-49 \\
50-59 \\
60-69\end{array}$ & $\begin{array}{r}55 \\
100 \\
88\end{array}$ & $\begin{array}{l}2 \\
25(3) \\
67(12)\end{array}$ & $\begin{array}{l}3 \\
7 \\
7\end{array}$ & $\begin{array}{r}60 \\
132 \\
162\end{array}$ & $\begin{array}{r}3 \\
19 \\
41\end{array}$ \\
\hline
\end{tabular}

Note: number of cases of atheromatous abdominal aortic aneurysms in parentheses 
Ischaemic heart disease, aortic aneurysms, and atherosclerosis in London

TABLE 9. PREVALENCE OF SEVERE ATHEROSCLEROSIS OF ABDOMINAL AORTA AT AUTOPSY IN FEMALES, ST BARTHOLOMEW'S HOSPITAL, 1893-97 TO 1978-82

\begin{tabular}{|c|c|c|c|c|c|}
\hline $\begin{array}{l}\text { Years and } \\
\text { Age-group (Yrs.) }\end{array}$ & $\begin{array}{l}\text { Slight/ } \\
\text { Moderate }\end{array}$ & Severe & $\begin{array}{l}\text { Not } \\
\text { recorded }\end{array}$ & Total & $\begin{array}{l}\text { \% Severe } \\
\text { of Total }\end{array}$ \\
\hline $\begin{array}{r}1893-97 \\
40-49 \\
50-59 \\
60-69\end{array}$ & $\begin{array}{l}73 \\
39 \\
17\end{array}$ & $\begin{array}{r}2 \\
5 \\
12\end{array}$ & $\begin{array}{l}39 \\
29 \\
26\end{array}$ & $\begin{array}{r}114 \\
73 \\
55\end{array}$ & $\begin{array}{r}2 \\
7 \\
22\end{array}$ \\
\hline $\begin{array}{r}1903-07 \\
40-49 \\
50-59 \\
60-69\end{array}$ & $\begin{array}{l}65 \\
51 \\
16\end{array}$ & $\begin{array}{r}2 \\
6 \\
11\end{array}$ & $\begin{array}{l}42 \\
31 \\
19\end{array}$ & $\begin{array}{r}109 \\
88 \\
46\end{array}$ & $\begin{array}{r}2 \\
7 \\
24\end{array}$ \\
\hline $\begin{array}{r}1913-17 \\
40-49 \\
50-59 \\
60-69\end{array}$ & $\begin{array}{l}70 \\
67 \\
38\end{array}$ & $\begin{array}{r}4 \\
9 \\
12\end{array}$ & $\begin{array}{l}2 \\
5 \\
3\end{array}$ & $\begin{array}{l}76 \\
81 \\
53\end{array}$ & $\begin{array}{r}5 \\
11 \\
23\end{array}$ \\
\hline $\begin{array}{r}1918-22 \\
40-49 \\
50-59 \\
60-69\end{array}$ & $\begin{array}{l}74 \\
70 \\
41\end{array}$ & $\begin{array}{c}0 \\
9 \\
15(1)\end{array}$ & $\begin{array}{l}5 \\
4 \\
4\end{array}$ & $\begin{array}{l}79 \\
83 \\
60\end{array}$ & $\begin{array}{r}<2 \\
11 \\
25\end{array}$ \\
\hline $\begin{array}{r}1923-27 \\
40-49 \\
50-59 \\
60-69\end{array}$ & $\begin{array}{l}84 \\
82 \\
36\end{array}$ & $\begin{array}{c}4 \\
14 \\
19(1)\end{array}$ & $\begin{array}{l}22 \\
10 \\
10\end{array}$ & $\begin{array}{r}110 \\
106 \\
65\end{array}$ & $\begin{array}{r}4 \\
13 \\
29\end{array}$ \\
\hline $\begin{array}{r}1933-37 \\
40-49 \\
50-59 \\
60-69\end{array}$ & $\begin{array}{l}78 \\
89 \\
64\end{array}$ & $\begin{array}{l}1 \\
9(1) \\
26\end{array}$ & $\begin{array}{l}3 \\
6 \\
6\end{array}$ & $\begin{array}{r}82 \\
104 \\
96\end{array}$ & $\begin{array}{r}1 \\
9 \\
27\end{array}$ \\
\hline $\begin{array}{r}1940-44 \\
40-49 \\
50-59 \\
60-69\end{array}$ & $\begin{array}{r}14 \\
15 \\
9\end{array}$ & $\begin{array}{l}0 \\
0 \\
6\end{array}$ & $\begin{array}{r}10 \\
13 \\
7\end{array}$ & $\begin{array}{l}24 \\
28 \\
22\end{array}$ & $\begin{array}{l}<4 \\
<4 \\
27\end{array}$ \\
\hline $\begin{array}{r}1945-49 \\
40-49 \\
50-59 \\
60-69\end{array}$ & $\begin{array}{l}39 \\
41 \\
30\end{array}$ & $\begin{array}{l}1 \\
4 \\
11\end{array}$ & $\begin{array}{l}2 \\
2 \\
2\end{array}$ & $\begin{array}{l}42 \\
47 \\
43\end{array}$ & $\begin{array}{r}2 \\
9 \\
26\end{array}$ \\
\hline $\begin{array}{r}1953-57 \\
40-49 \\
50-59 \\
60-69\end{array}$ & $\begin{array}{r}72 \\
110 \\
87\end{array}$ & $\begin{array}{l}1 \\
10 \\
17(1)\end{array}$ & $\begin{array}{r}8 \\
12 \\
12\end{array}$ & $\begin{array}{r}81 \\
132 \\
116\end{array}$ & $\begin{array}{r}1 \\
8 \\
15\end{array}$ \\
\hline $\begin{array}{r}1963-67 \\
40-49 \\
50-59 \\
60-69\end{array}$ & $\begin{array}{r}59 \\
122 \\
177\end{array}$ & $\begin{array}{c}2 \\
13 \\
32(2)\end{array}$ & $\begin{array}{l}2 \\
2 \\
4\end{array}$ & $\begin{array}{r}63 \\
137 \\
153\end{array}$ & $\begin{array}{r}3 \\
9 \\
21\end{array}$ \\
\hline $\begin{array}{r}1973-77 \\
40-49 \\
50-59 \\
60-69\end{array}$ & $\begin{array}{r}63 \\
100 \\
103\end{array}$ & $\begin{array}{r}3 \\
9 \\
36\end{array}$ & $\begin{array}{l}1 \\
2 \\
7\end{array}$ & $\begin{array}{r}67 \\
111 \\
146\end{array}$ & $\begin{array}{r}4 \\
8 \\
25\end{array}$ \\
\hline $\begin{array}{r}1978-82 \\
40-49 \\
50-59 \\
60-69\end{array}$ & $\begin{array}{l}34 \\
79 \\
98\end{array}$ & $\begin{array}{c}2 \\
15 \\
36(1)\end{array}$ & $\begin{array}{l}4 \\
3 \\
4\end{array}$ & $\begin{array}{r}40 \\
97 \\
138\end{array}$ & $\begin{array}{r}5 \\
15 \\
26\end{array}$ \\
\hline
\end{tabular}

Note: figures in brackets as in Table 8. 


\section{R. Finlayson}
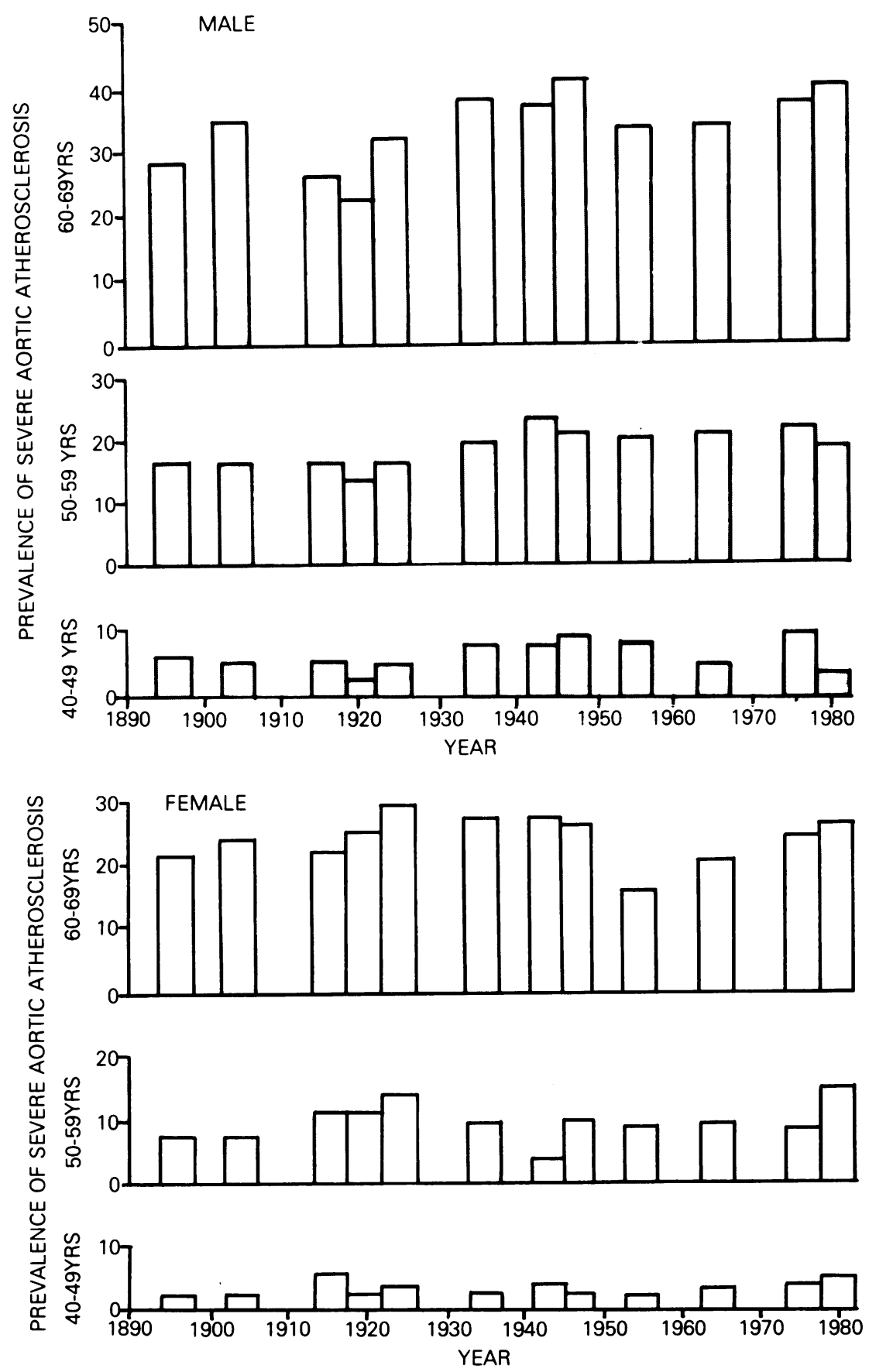

Figure 1. Histograms outlining the prevalence of severe atherosclerosis of the abdominal aorta in men and women aged 40-49, 50-59, and 60-69 years on autopsy at St Bartholomew's Hospital, 1893-97 to 1978-82. 
Ischaemic heart disease, aortic aneurysms, and atherosclerosis in London

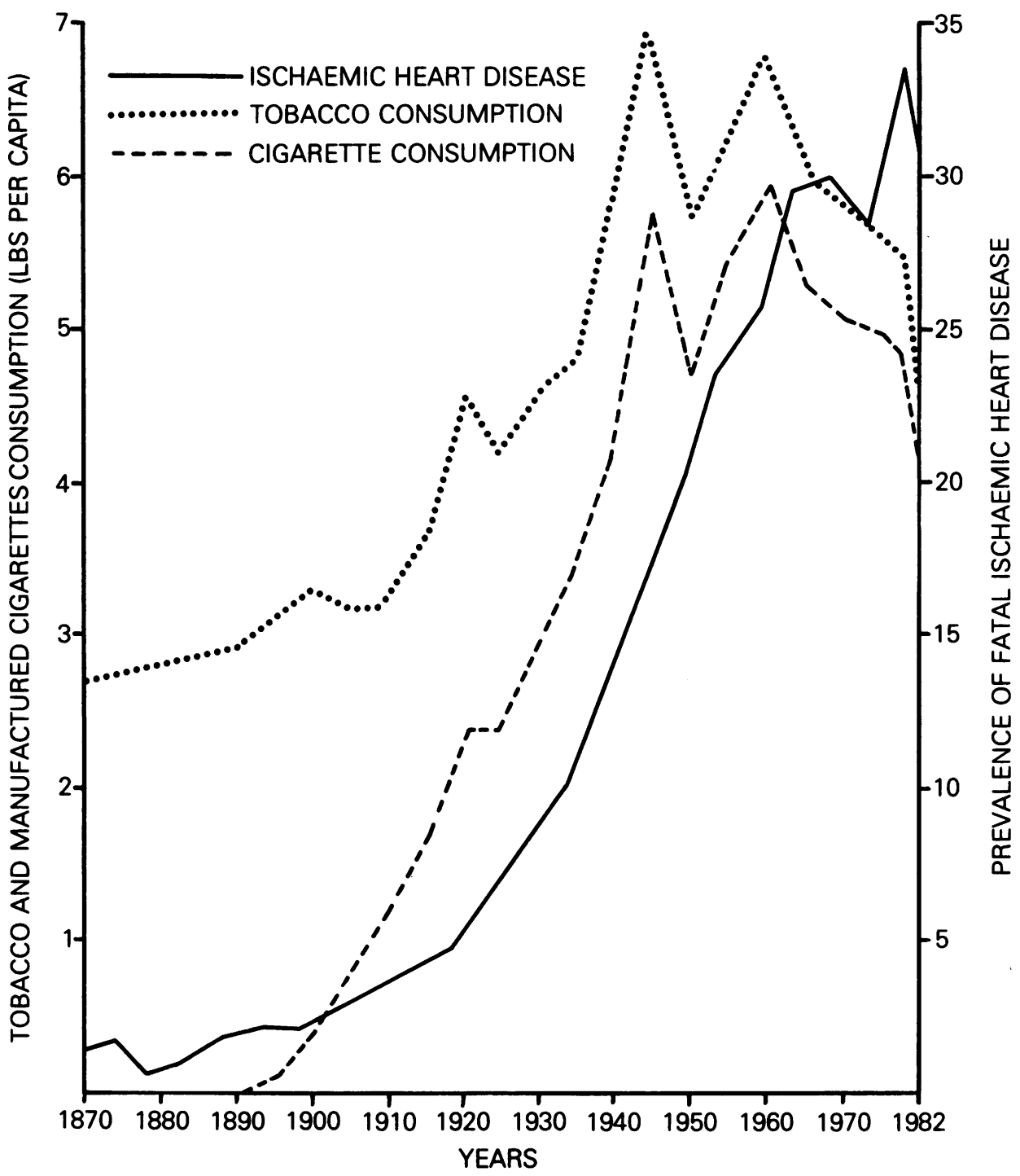

Figure 2. A graph relating the prevalence of fatal ischaemic heart disease in patients, forty years and older, subjected to autopsy at St Bartholomew's Hospital or at the City of London mortuary from 1870 to 1982 , to the annual consumption of all tobacco goods and of manufactured cigarettes per capita over the age of fifteen years in the United Kingdom. ${ }^{7,8}$

Few would dispute that there is an important relationship between coronary atherosclerosis and ischaemic heart disease, and between aortic atherosclerosis and aneurysms of the abdominal aorta, but what might be questioned is the almost tacit assumption that a surge in the intensity of atherosclerosis and its causative factors is responsible for the massive increase in coronary heart disease during the present

${ }^{7}$ P.N. Lee (editor), Statistics of smoking in the United Kingdom, Research Paper 1, 7th ed., London, Tobacco Research Council, 1976, pp. 21-23.

A.W.M. St. Aubyn, personal communication. 


\section{R. Finlayson}

century and the much more modest increase in abdominal aneurysms over the past three decades. Indeed, two such surges would need to be postulated: atheromatous aneurysms usually present later in life than ischaemic heart disease, but a thirty-five-year dissociation is about double the time interval one might have expected if a common causal factor had been implicated. Assuming, however, that atherosclerosis has not become more severe in the population of the City and East London since the end of the nineteenth century, then, apart from the increasing age of the population, it would seem that an additional factor has triggered off the epidemic of coronary heart disease, and possibly yet another factor has caused the more recent and more modest increase in abdominal aortic aneurysms.

Hypercholesterolaemia, hypertension, and smoking are currently regarded as the major predictors of ischaemic heart disease, and, accepting that the habit of smoking manufactured cigarettes by Londoners has matched that by the population of the United Kingdom as a whole, then the prevalence of coronary deaths in the City during the present century has followed the per capita consumption of cigarettes with almost relentless consistency (Figure 2). Of the many dietary factors that have been considered in the aetiology of ischaemic heart disease, eggs, butter and saturated animal fats in general have probably attracted the most attention. In this respect, it is interesting to note from Orr ${ }^{9}$ that, with the exception of wheat flour, potatoes, and meat, there was a substantial increase in the consumption of most of the principal foods in the United Kingdom between 1909-13 and 1934; the largest increase being fruit, vegetables, butter, and eggs, On the other hand, between 1909-13 and 1924-28, margarine consumption showed the highest percentage increase, whilst that of eggs only increased slightly and that of butter remained unchanged. Between 1928 and 1934, margarine consumption fell by one-third, while butter consumption increased by 57 per cent: an increase that coincided with a fall of 48 per cent in its price. Subsequently, margarine sales have burgeoned, and if one is correct in stating that the coronary disease epidemic started in the second decade of this century, then the concept of hydrogenated margarines as an important aetiological factor, so strongly advocated by Martin, ${ }^{10,11}$ may merit more consideration than hitherto.

Initially, the prevalence of atheromatous aneurysms of the abdominal aorta in the survey was to be used as an index of severe aortic atherosclerosis, but the results suggest that it is about as unreliable as the frequency of cardiac rupture is as an index of myocardial infarction. Systemic hypertension is an important factor in the pathogenesis of atheromatous aneurysms, ${ }^{12}$ and the use of modern anti-hypertensive agents may, in a perverse way, have contributed to the recent increase in these aneurysms in that some erstwhile hypertensive patients, who previously would have died from the effects of their high blood pressure, now survive and present with an aneurysm later in life. However, a major factor in the fairly sharp and recent increase in aneurysms in both the hospital and City mortuary post-mortem series can almost

9 John Boyd Orr, Food, health and income, London, Macmillan, 1936, pp. 18-19.

${ }^{10}$ Wayne Martin, letter, Lancet, 1983, ii: 407.

${ }^{11}$ Wayne Martin, 'The combined role of atheroma, cholesterol, platelets, the endothelium and fibrin in heart attacks and strokes'. Med. Hypoth., 1984, 15: 305-322.

${ }^{12}$ Ira Gore and A.E. Hurst jun., 'Arteriosclerotic aneurysms of the abdominal aorta: a review', Progr. Cardiovasc. Dis., 1973, 16: 113-150. 
Ischaemic heart disease, aortic aneurysms, and atherosclerosis in London

certainly be related to the developments in reparative and replacement vascular surgery, although the onset of the increased prevalance probably antedated modern surgical therapy by a few years.

In retrospect, the better documentation of cerebral haemorrhage might have made it a wiser choice for historical review than ischaemic heart disease and atherosclerosis, but at least one can commend the records of the Coroner's Court as a rich, if somewhat macabre and specialized, source of recent and comparatively recent social history.

A second valuable record, complementary to the hospital's post-mortem register and to which brief reference has been made, is the register of deaths at the hospital. This dates back to 1838 , and it is of interest that in a recent sample analysis of the records from 1839 to 1872 , Forbes ${ }^{13}$ noted that heart disease-cardiac enlargement, valvular disease, mitral constriction, aortic regurgitation, rheumatic heart disease, pericarditis-ranked second to tuberculosis as the greatest single cause of non-traumatic death. He also commented in his analysis that although only one autopsy of a patient dying at the hospital was noted in the registers for 1839-42, in 1850 and thereafter (to 1872) post-mortem examinations were made in 41-60 per cent of all patient deaths. A sample analysis of the death registers from $1868^{14}$ showed a post-mortem rate of 55 per cent in that year with a marked increase in the 1870 s which was maintained into the first decade of the present century when the post mortems peaked at 80 per cent of all patient deaths. Thereafter, the rate dropped, fluctuating between about 45 and 65 per cent, but with no evidence to suggest any selectivity in the performance of autopsies on those dying from heart disease apart from that determined by the Coroner.

\section{ACKNOWLEDGEMENTS}

This study would not have been possible without the active co-operation of several people including the staff of the Pathology Department and Library, St Bartholomew's Hospital; Miss Janet Foster, District Archivist at St Bartholomew's Hospital; Dr D.M. Paul, Her Majesty's Coroner for the City of London, and his officers; the staff at the Corporation of London Records Office, Guildhall; the Tobacco Research Council; my colleagues at the Wellcome Museum of Medical Science, and, more passively, by those who wrote the post-mortem reports. I thank them all, and especially Miss Janet Foster for her analysis of the death registers at the hospital.

\footnotetext{
${ }^{13}$ Thomas R. Forbes, 'Mortality at St. Bartholomew's Hospital, London, 1839-72', J. hist. Med., 1983, 38: 432-499.

14 Janet Foster, unpublished data.
} 


\section{R. Finlayson}

\section{APPENDIX I}

Post Mortem No.256, 1868

Name James Forster Age 54 Admitted Dec. 3rd. Died Dec. 3rd. Under the care of Dr. Church Examination at what Time afterdeath 18 hours

History: was admitted suffering great pain in the thorax and epigastrium.

After being in the ward about 10 or 15 minutes he expired. His wife stated that during the last few weeks he had been unable to walk to and from his work as a compositor, walking bringing on pain in the chest, but with that exception he had appeared to be in his ordinary health.

Body fat. Rigor Mortis considerable.

Pleurae the right contained a few firm adhesions at posterior portion of upper lobe.

Lungs The right where the pleura was adherent to costal parietes, Much puckered but not much cicatrix tissue in it. In the midst of the puckered portion was an old irregularly shaped cretified mass. The posterior parts of the lungs were very oedematous and they were generally emphysematous.

Pericardium contained about 2 ozs. of slightly turbid serum. The heart was flabby semicontracted.

Heart all its cavities contained fluid blood. The valves competent aortic a little thickened, the mitral contained some atheroma, and a little was scattered about at the origin of the aorta. The orifices of the coronary arteries 3 in $\mathrm{N}^{\circ}$. were natural, but their walls soon became calcified and that of the right obliterated. The muscular tissue was pale and friable and so rotten that it would not bear the weight of the heart $12 \frac{1}{2}$ ozs.

Liver large its surface smooth edges rounded a little. On section pale soft and fatty. W. 4 lbs 12 ozs.

Kidneys the subperitoneal tissue about them loaded with fat. Capsule a little adherent surface rather pale with congestion of stellate veins. On section a little streaky but looked pretty healthy. W together $9 \frac{3}{4}$ ozs.

Bladder empty

Stomach contained the undigested remains of a hearty meal of meat etc.

Intestines not examined

Blood throughout the body was fluid vid. No 208.

On a Microscopical Examination of the muscular tissue of the heart the striae were found almost wholly wanting and the muscular tissue atrophied, but only dimly granular, no oil molecules being observable; but scarcely any fibres could be found in which the striae were well marked.

Nature of Disease Angina Pectoris. Degeneration of Muscles of the Heart. Ossification (and obliteration of one) of coronary arteries. 
Ischaemic heart disease, aortic aneurysms, and atherosclerosis in London

Post Mortem No.391, 1875

Name Louth John Spilling Age Admitted Died Aug. 311875 Under the care of

Examination at what Time after death 24 hours

Brought in dead.

He was walking in the City with his friends when he fell down dead.

Body extremely fat.

Nothing in head, lung, liver, kidneys, spleen or intestines.

The heart very flabby: muscular tissue soft and easily broken; but the papillary muscles are not striated. Under microscope muscular fibres extensively fattily degenerated; not much atheroma of valves; extensive calcification of coronary artery.

Stomach full of a large meal of meat and other things: the meat in large pieces bolted whole.

Nature of Disease Fatty Heart

\section{APPENDIX II}

Post Mortem No.23, 1870

$\begin{array}{llcccc}\text { Name James Roper } & \text { Age } & 58 & \text { Admitted April 25 Died April } 25 \\ \text { Under the care of } & & \text { Examination at what Time after death } 62 \text { hours. }\end{array}$ Brought in dead.

Body fat, rigor mortis persistent.

Brain Calvaria, dura mater, and meninges normal. Substance of brain firmer than natural; the red points not numerous. About a drachm of clear serosity in each lateral ventricle; no morbid appearances.

Sinuses healthy

Pleurae and contain a sanguinolent fluid.

Pericardium

Lungs

Heart

Rt $35 \frac{1}{2}$ oz. Bronchial tubes hyperaemic; the lung substance contains patches of tissue ranging in size from walnut to a pea, which on section present numerous miliary tubercles. In some places the bronchial tubes are dilated but there are no true cavities. L. $27 \mathrm{oz}$. The apex contains a lump of cheesy matter the size of a pea and miliary tubercles are scattered throughout substance. The bronchial tubes are frequently dilated. Both lungs are emphysematous.

$14 \mathrm{oz}$; extremely flabby and of a brownish yellow appearance on section. Valves natural, endocardium deeply stained.

Liver $\quad 57 \mathrm{oz}$, natural as far as decomposition will allow an opinion to be formed.

Spleen $\quad 7 \mathrm{oz}$; extremely soft.

Kidneys $\quad 7 \mathrm{oz}$; small contracted granular. Bladder empty.

Aorta and atheromatous; the aorta is in many places calcified.

large arteries

Nature of Disease Fatty heart: atheromatous arteries Interstitial nephritis. 


\section{R. Finlayson}

Post Mortem No.173, 1884

Name Dye Sarah Age 71 y Date ofadmission Oct.23 Date of Death Oct.24

Under the care of Dr. Andrew Date of Post-mortem Oct.25

Ward Hope Reference Heart preserved and Calvaria-Museum [sic]. External Appearances Very fat. No anasarca.

Head:

Cranial Bones

Calvaria enormously thick with many internal corrugated bosses.

Dura Mater and Sinuses not thickened

Arachnoid and Pia Mater $\mathbf{n}$

Arteries

Brain

Spinal Cord

Eye $\quad x$

Ear $\quad x$

Chest:

Oesophagus n

Glands of Neck $n$

Larynx and Trachea $n$

Lungs

Heart

atheromatous

substance normal.

$\mathrm{x}$

$\mathbf{x}$

n

n

slightly emphysematous, otherwise $\mathbf{n}$.

The pericardium was externally entire. On opening it was found full of blood and half way down in the right ventricle in front was a discoloured patch of muscular tissue in which there were two small rents. These led directly into the right ventricle and there was a small piece of soft recent clot lying in one of them.

Aorta and Vessels highly atheromatous

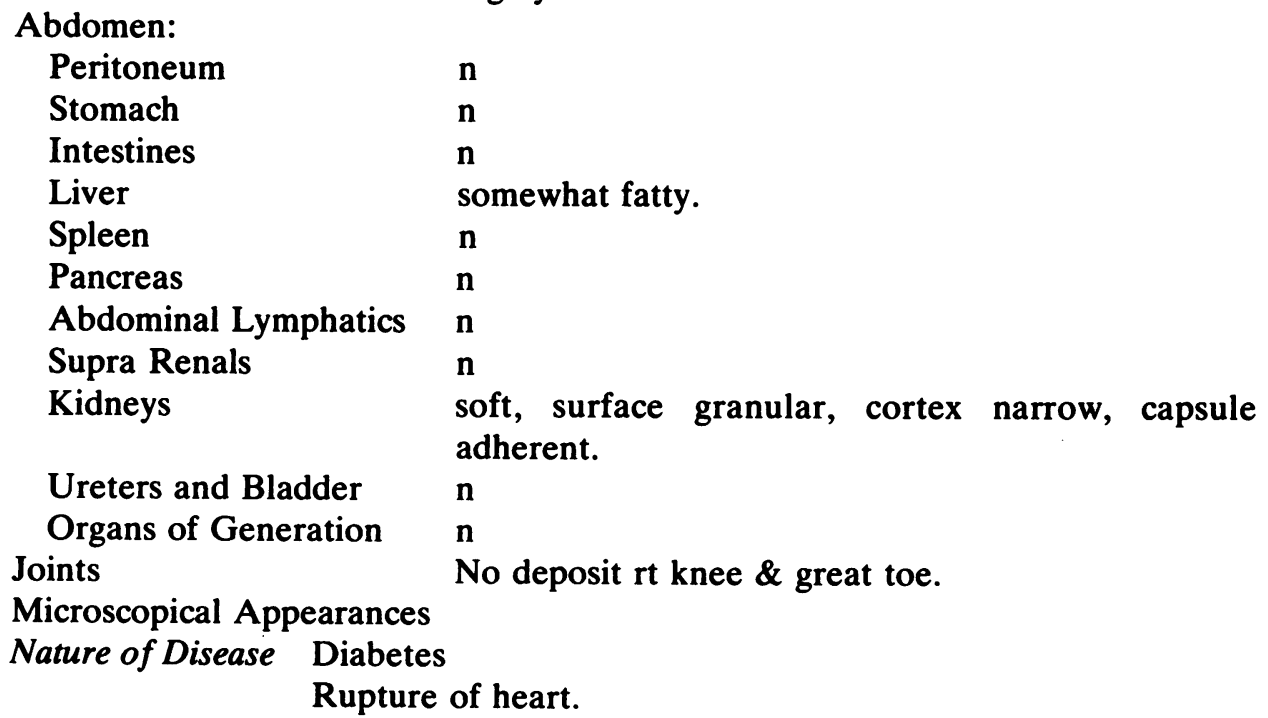

